\begin{tabular}{ccc} 
Tersedia online di: http://ejournal-balitbang.kkp.go.id/index.php/jppi & JURNAL \\
e-mail:jppi.puslitbangkan@ gmail.com & PEVLITIAN \\
PERIKANAN & INDONESIA \\
JURNALPENELITIANPERIKANANINDONESIA & Volume 24 Nomor 3 September 2018 \\
p-ISSN: 0853-5884 & e-ISSN: 2502-6542 \\
Nomor Akreditasi RISTEKDIKTI: 21/E/KPT/2018 & \\
\hline
\end{tabular}

\title{
PENGARUH UKURAN MATA JARING BUBU LIPAT TERHADAP JUMLAH DAN UKURAN HASIL TANGKAPAN RAJUNGAN DI PERAIRAN UTARA LAMONGAN, JAWA TIMUR
}

\section{EFFECT OF DIFFERENT MESH SIZE TO THE CATCHES OF COLLAPSIBLE POT FOR BLUE SWIMMING CRAB (BSC) IN NORTHERN WATERS OF LAMONGAN, EAST JAWA}

\author{
Mahiswara*1, Hufiadi', Baihaqi' dan Tri Wahyu Budiarti' \\ 1Balai Riset Perikanan Laut, Jl. Raya Bogor Km. 47 Nanggewer Mekar-Cibinong, Bogor 16912, \\ Teregistrasi I tanggal: 26 Januari 2018; Diterima setelah perbaikan tanggal: 19 Juli 2018; \\ Disetujui terbit tanggal: 25 Juli 2018
}

\begin{abstract}
ABSTRAK
Bubu lipat merupakan alat tangkap yang banyak dioperasikan nelayan untuk menangkap rajungan, namun memiliki selektivitas rendah tergantung pada ukuran mata jaring yang digunakan. Tingkat selektivitas bubu lipat perlu ditingkatkan agar tangkapan rajungan memiliki ukuran layak tangkap sesuai peraturan. Penelitian uji coba pengoperasian bubu lipat rajungan dengan berbagai ukuran mata jaring yaitu 11/4,2, 21/2 dan 3 inci, berbentuk bujur sangkar telah dilakukan di perairan utara Lamongan, Jawa Timur. Jumlah bubu lipat yang dioperasikan untuk setiap ukuran mata jaring sebanyak 150 unit per tawur/setting. Tujuan penelitian, untuk mengetahui pengaruh ukuran mata jaring bubu terhadap jumlah dan ukuran hasil tangkapan rajungan. Hasil analisis menunjukkan bahwa perbedaan ukuran mata jaring berpengaruh nyata terhadap hasil tangkapan bubu lipat rajungan. Hasil tangkapan rajungan dari bubu lipat mata jaring 2 inci $(2,17 \mathrm{~kg} / \mathrm{setting})$ tidak berbeda nyata dengan mata jaring $1 \frac{114}{4}$ inci $(2,08 \mathrm{~kg} / \mathrm{setting})$. Ukuran lebar karapas $(C W=$ carapace width) rajungan layak tangkap $(>100 \mathrm{~mm})$ semakin besar dengan meningkatnya ukuran mata jaring. Nilai tertinggi prosentase tangkapan rajungan ukuran besar $\left(\mathrm{C}_{\mathrm{w}}>100 \mathrm{~mm}\right)$, ditemukan pada bubu lipat ukuran mata jaring 3 inci mencapai $98 \%$ dari total rajungan yang tertangkap.
\end{abstract}

Kata Kunci: Bubu lipat; hasil tangkapan; rajungan; ukuran mata jaring; selektivitas

\begin{abstract}
Collapsible crab pot is a common fishing gear that has been operated by many fishermen, however this kind of fishing gear has a low selectivity. The selectivity level of crab pot needs to be increased so that the size of crab catch comply to the allowable legal size. Fishing trials of crab pot with the mesh size of 11/4,2,21/2 and 3 inch square-shaped has been done in the waters of north Lamongan, East Java. The objectives of this research is to determine the effect of mesh size to the number and size of the catches. The results showed that different mesh size has significant effect on the catch of pot. However the catch of a 2 inch mesh size pot (of $2.17 \mathrm{~kg} / \mathrm{setting}$ ) was not significantly different with the catch of pot with 11/4 inch mesh size (of $2.08 \mathrm{~kg} / \mathrm{setting}$ ). Percentage of BSC catch with carapace width $\left(C_{w}\right)>100 \mathrm{~mm}$ increased by increasing $\theta$ mesh size of net. The highest percentage (98\% of the total catch) was obtained from the 3-inch mesh sizes.
\end{abstract}

Keywords: Collapsible pot; catch; blue swimming crab/BSC; mesh size; selectivity 


\section{PENDAHULUAN}

Usaha perikanan rajungan (blue swimming crab/ BSC, Portunus pelagicus) memberikan kesempatan kerja yang luas dan menjadi sumber pendapatan utama sebagian nelayan di pantai utara Jawa. Rajungan telah menjadi komoditas yang memiliki nilai ekonomis tinggi semenjak masuk kategori produk ekspor utama perikanan sejak tahun 2005. Meskipun mengalami fluktuasi tahunan, produksi perikanan rajungan pada periode 2010 - 2015 cenderung meningkat. Pada tahun 2010 produksi perikanan rajungan di Indonesia tercatat sebanyak 43.002 ton, meningkat menjadi 88.455 ton pada tahun 2015 (DJPT, 2016).

Kebutuhan akan pasokan dan kemudahan akses pemasaran, menjadikan kegiatan penangkapan rajungan semakin intensif dilakukan nelayan. Jenis alat tangkap yang digunakan nelayan untuk menangkap rajungan adalah bubu (crab pots) termasuk bubu lipat, jaring insang (gill net), garuk (dredge) dan pukat dasar (bottom seine net). Pengoperasian alat tangkap bubu lipat yang dianggap lebih selektif, dan telah banyak dioperasikan oleh nelayan untuk meningkatkan hasil tangkapan, ternyata memiliki dampak negatif terhadap populasi sumberdaya rajungan. Bubu lipat rajungan yang umum dioperasikan nelayan menggunakan ukuran mata jaring sangat kecil yaitu $1 \frac{1}{4} 4$ inci. Berdasarkan hasil penelitian terhadap pemanfaatan sumber daya rajungan di perairan Belitung dan sekitarnya, yang menggunakan bubu lipat sebagai alat penangkapan rajungan utama, menunjukkan indikasi terjadinya penangkapan berlebih (overfishing) ditandai dengan menurunnya hasil tangkapan dan ukuran individu semakin kecil (Ernawati et al., 2015). Tertangkapnya rajungan yang masih berukuran kecil, menunjukkan bahwa bubu lipat bermata jaring kecil yang dioperasikan untuk menangkap rajungan tergolong alat tangkap yang kurang selektif.

Meskipun bubu dikategorikan sebagai alat penangkap ikan yang ramah lingkungan, namun pengoperasian bubu dalam jumlah banyak dan tanpa pengendalian dapat berdampak negatif terhadap populasi rajungan. Selektivitas bubu terhadap jenis maupun ukuran target spesies ditentukan oleh rancang bangun dan kontsruksi bubu, tipe, jumlah dan ukuran mulut bubu, ukuran mata jaring ataupun lebar kisi, daerah dan waktu pengoperasian. Bubu lipat yang telah berkembang di masyarakat nelayan, cenderung memiliki selektivitas yang rendah terhadap ukuran hasil tangkap rajungan. Keadaan ini terindikasi dengan ikut tertangkapnya rajungan berukuran kecil, yang ditengarai belum layak tangkap. Masalah keberlanjutan sumberdaya rajungan timbul seiring dengan meningkatnya permintaan pasar, yang mengakibatkan meningkatnya jumlah upaya penangkapan, dan penggunaan alat tangkap yang tidak selektif.

Berdasarkan Peraturan Kementerian Kelautan Perikanan, Men.KP 01/Tahun 2015 telah ditetapkan rajungan yang boleh ditangkap harus berukuran lebar karapas (CW: carapace width) lebih dari $10 \mathrm{~cm}$ (100 $\mathrm{mm}$ ). Dalam peraturan tersebut berarti tidak diperbolehkan untuk melakukan penangkapan rajungan dalam kondisi bertelur dan yang berukuran lebar karapas $<10 \mathrm{~cm}$. Dengan diterapkan peraturan ini memberikan konsekuensi terhadap alat tangkap dan cara penangkapan rajungan agar dalam pengoperasiannya menghindari tertangkapnya rajungan yang sedang bertelur dan juga rajungan muda (berukuran kurang dari lebar kapapas $/ \mathrm{CW}=10 \mathrm{~cm}$ ).

Bubu lipat merupakan alat tangkap rajungan (Portunus pelagicus) yang paling selektif dibandingkan dengan alat tangkap jarring kejer (gillnet), garuk dan jarring arad (Hufiadi, 2017). Beberapa penelitian telah dilakukan untuk lebih meningkatkan kinerja selektifitas alat tangkap bubu lipat rajungan, salah satunya dengan memberikan celah pelolosan (escape gap) pada dinding bubu yang dibuat bahan dari jaring (Jirapunpipat et al., 2008; Boutson et al., 2009; Susanto \& Irnawati, 2013; Tallo et al., 2014; Pangalila \& Labaro, 2016; Kurniasih et al., 2016; La Sara et al., 2016). Upaya mengurangi ataupun menghindari tertangkapnya rajungan muda pada alat tangkap bubu lipat dapat dilakukan melalui; modifikasi rancang bangun, kontruksi, pengaturan daerah penangkapan dan musim pengoperasian. Dalam upaya memperoleh rancang bangun dan kontruksi alat tangkap bubu lipat yang selektif terhadap ukuran hasil tangkapan rajungan namun mampu memperoleh hasil tangkapan tinggi, maka telah dilakukan penelitian penggunaan ukuran mata jaring yang berbeda. Penelitian bertujuan untuk menentukan kinerja bubu lipat yang menggunakan ukuran mata jaring berbeda, dan bagaimana pengaruhnya terhadap jumlah dan ukuran hasil tangkapan rajungan.

\section{BAHAN DAN METODE Pengumpulan Data}

Penelitian uji coba operasi penangkapan bubu lipat rajungan dilaksanakan pada periode Juni - September 2015 di Laut Jawa tepatnya di wilayah perairan utara Brondong, Lamongan - Jawa Timur (Gambar 1). Bubu lipat rajungan dioperasikan pada perairan dengan kedalaman antara 7-22 meter. 


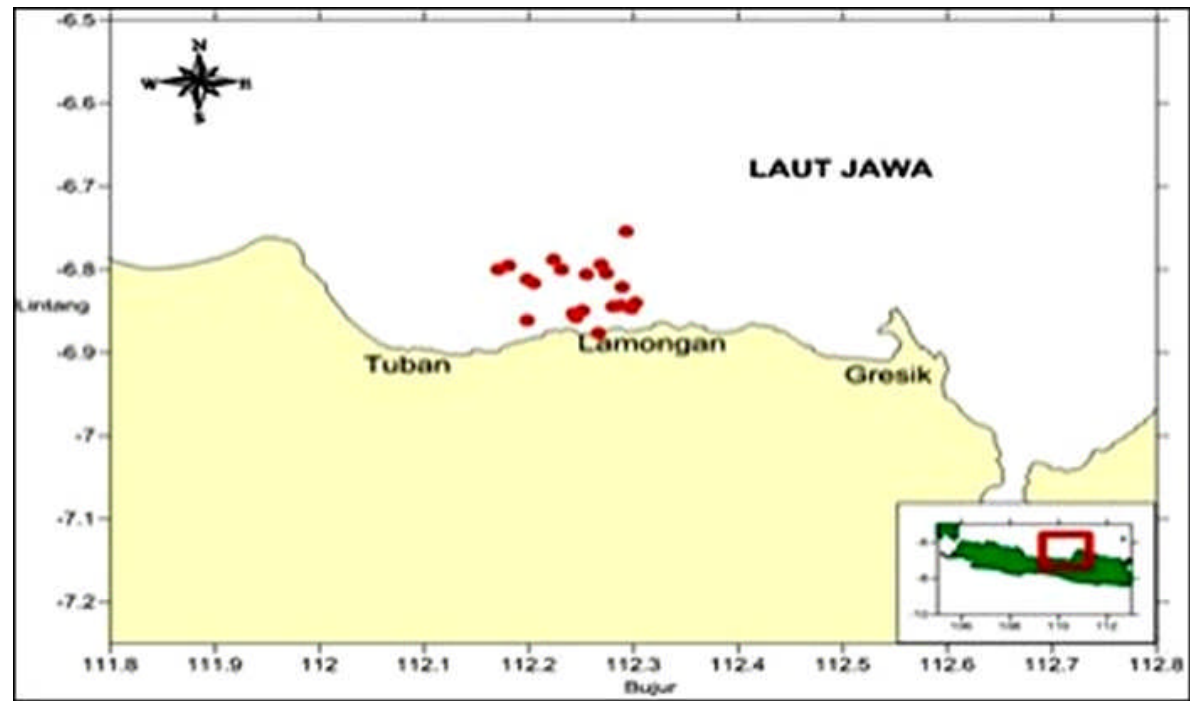

Gambar 1. Lokasi uji coba bubu lipat untuk menangkap rajungan (titik merah menunjukkan posisi pengoperasian bubu lipat).

Figure 1. Location of collapsible pot fishing trials for catching blue swimming crab (red dot indicated position of the fishing trials).

Dalam penelitian ini digunakan tipe bubu lipat yang konstruksinya terdiri dari beberapa bagian yaitu pintu masuk/mulut bubu (ijab-ijab) berada di bagian sisi/ samping, ruang perangkap dan tempat dipasangnya umpan. Rangka bubu lipat dibuat dari bahan besi berdiameter $4 \mathrm{~mm}$, dengan ukuran panjang $(\mathrm{P})$, lebar (L) dan tinggi (t) : $(45 \times 30 \times 20) \mathrm{cm}^{3}$. Bahan jaring polyethelene $(\mathrm{PE} \mathrm{d} / 9)$ digunakan sebagai dinding bubu yang dipasang membentuk square mesh (bujur sangkar), berukuran mata jaring $1 \frac{1 / 4}{4}$ inci (tipe bubu A), 2 inci (tipe bubu B), 21/2 inci (tipe bubu C) dan 3 inci (tipe bubu D). Maksimum bukaan bagian mulut bubu (ijab-ijab) secara vertikal setinggi $6 \mathrm{~cm}$ dan secara horisontal selebar $30 \mathrm{~cm}$. Konstruksi dan dimensi kerangka bubu lipat rajungan disajikan pada Gambar 2.
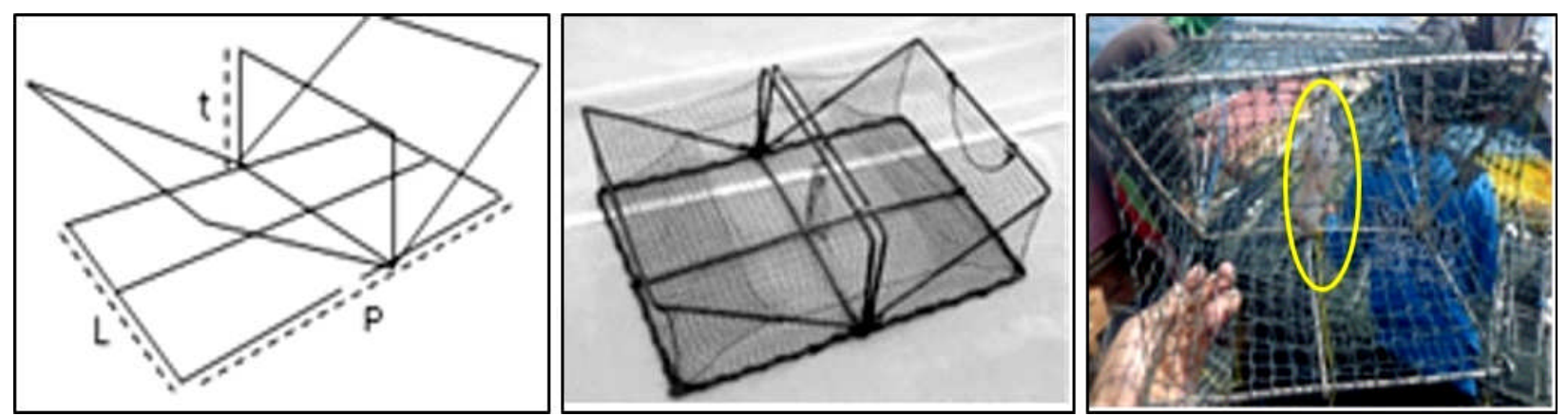

Gambar 2. Desain dan kontsruksi bubu lipat untuk menangkap rajungan.

Figure 2. Design and construction of collapsible pot for catching blue swimming crab.

Pengoperasian bubu rajungan menggunakan umpan jenis ikan petek (Leiognathidae) yang telah dibusukkan sehingga aromanya dapat memikat rajungan masuk ke dalam bubu. Umpan dipasang di dalam bubu dengan cara digantungkan (Gambar 2). Pada setiap bubu dipasang umpan dengan berat antara 100-150 gram, untuk setiap kali pengoperasian (setting).

Metode penelitian yang digunakan adalah uji coba penangkapan dengan 4 tipe bubu, dengan perlakuan ukuran mata jaring yaitu; 11/4 inci (bubu A), 2 inci (bubu B), 21/2 inci (bubu C) dan 3 inci (bubu D). Pada setiap kali operasi penangkapan digunakan sebanyak 150 unit bubu lipat untuk masing masing tipe bubu sehingga total bubu keseluruhan berjumlah 600 unit. Sebanyak 29 (dua puluh sembilan) kali ulangan pengoperasian bubu (setting) dilakukan selama penelitian. Pengoperasian keempat bubu dengan ukuran mata jarring berbeda dilakukan secara berbarengan pada setiap setting, dan disusun secara berselang seling (Gambar 3) sehingga peluang untuk menangkap rajungan menjadi sama. Bubu lipat rajungan dioperasikan di daerah penangkapan dengan kisaran kedalaman perairan antara 7-22 meter. Data dan informasi yang dihimpun selama penelitian adalah 
komposisi jenis dan bobot hasil tangkapan, bobot dan ukuran individu rajungan sebagai target utama penangkapan, serta data operasional pengoperasian bubu lipat rajungan.

Dalam pengoperasiannya, bubu dilengkapi dengan tali utama, untuk menggantungkan bubu dengan tali cabang. Tali utama menggunakan bahan PE dengan ukuran diameter $10 \mathrm{~mm}$. Tali cabang, yang menghubungkan bubu dengan tali utama sepanjang 4,5 m dengan bahan dan ukuran sama dengan tali utama yaitu $P E 10 \mathrm{~mm}$. Jarak pemasangan antara bubu yang diikatkan pada tali utama sepanjang 15 meter.

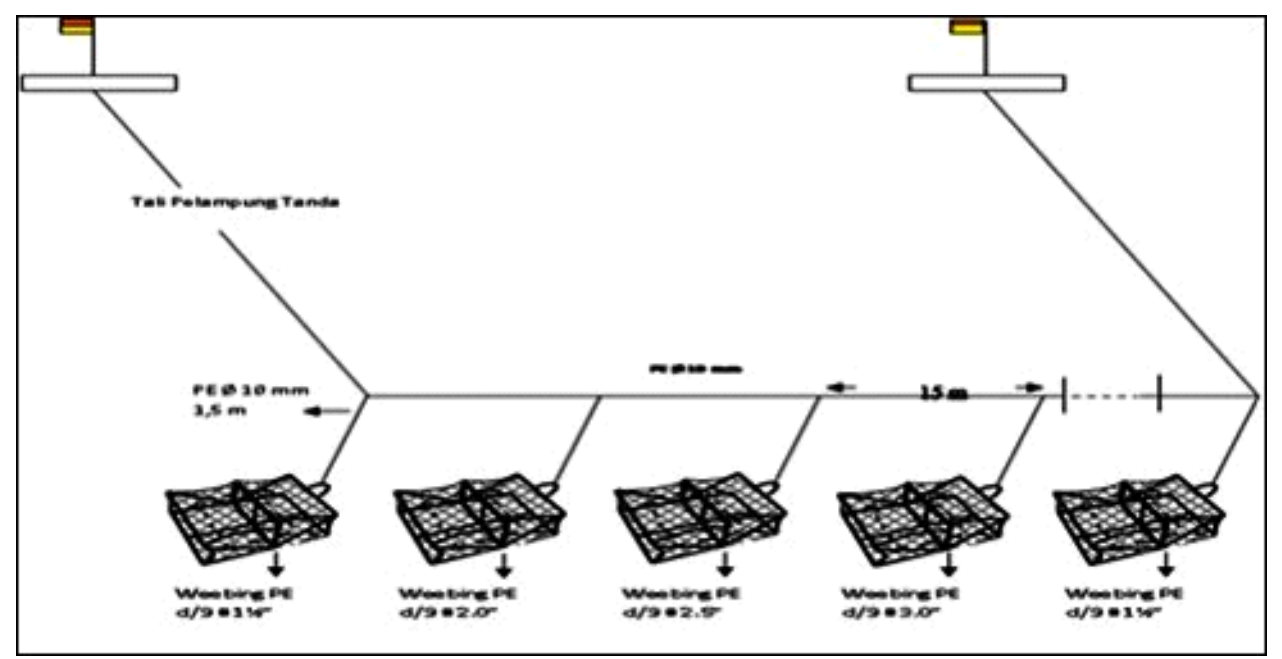

Gambar 3. Konfigurasi pemasangan bubu lipat saat uji coba penangkapan.

Figure 3. Performance of collapsible pot position during fishing trial.

Hasil tangkapan setiap tipe bubu (ukuran mata jarring berbeda) dipisahkan berdasarkan jenis, kemudian dikategorikan antara rajungan sebagai hasil tangkapan target dan jenis biota yang lain sebagai hasil tangkapan sampingan (by catch). Hasil tangkapan bubu yang telah dipisahkan berdasarkan jenisnya kemudian ditimbang dengan menggunakan timbangan berkapasitas $10 \mathrm{~kg}$, dengan tingkat ketelitian $0,1 \mathrm{~kg}$. Setiap individu rajungan hasil tangkapan diukur lebar karapasnya menggunakan alat digital caliper dalam satuan $\mathrm{mm}$ dengan tingkat ketelitian $0,1 \mathrm{~mm}$.

\section{Analisis Data}

Untuk mengetahui pengaruh ukuran mata jaring bubu lipat terhadap hasil tangkapan rajungan melalui uji coba pengoperasian, digunakan Rancangan Acak.

Kelompok. Dalam uji coba sebagai perlakuan digunakan tipe bubu dengan ukuran mata jarring (11/4, 2, 21/2, 3 inci) dan operasi penangkapan (setting) sebagai kelompok. Data hasil tangkapan kemudian diolah, dianalisis dengan menggunakan analisis sidik ragam (ANOVA) untuk mendapatkan nilai $F_{\text {Hitung }}$ kemudian dibandingkan dengan nilai $F_{\text {Tabel }}$ dengan ketentuan sebagai berikut:

a. Jika nilai $\mathrm{F}_{\text {Hitung }}>\mathrm{F}_{\text {Tabel (1\%) }}$; perlakuan dikatakan berbeda sangat nyata, pada taraf $1 \%(\alpha=0,01)$ b. Jika $\mathrm{F}_{\text {Tabel (5\%) }}<\mathrm{F}_{\text {Hitung }}<\mathrm{F}_{\text {Tabel }(1 \%)}$; perlakuan dikatakan berbeda nyata, pada taraf $1 \%(\alpha=$ 0,01),

c. Jika $\mathrm{F}_{\text {Hitung }}$ d" $\mathrm{F}_{\text {Tabel (5\%) }}$; perlakuan dikatakan tidak berbeda nyata, pada taraf $5 \%(\alpha=0,05)$.

Jika hasil uji menghasilkan nilai $F_{\text {hitung }}<\mathrm{F}_{\text {tabel }}$ maka terima $\mathrm{H}_{0}$ dan jika $\mathrm{F}_{\text {hitung }}>\mathrm{F}_{\text {tabel }}$ tolak $\mathrm{H}_{0}$ yang berarti terdapat pengaruh ukuran mata jaring terhadap hasil tangkapan (terima $\mathrm{H}_{1}$ ). Apabila hasil uji F memberikan kesimpulan berbeda nyata maka dilanjutkan dengan uji Beda Nyata Terkecil (BNT) untuk mengetahui perlakuan yang memberikan hasil tangkapan terbaik dengan membandingkan selisih rata-rata perlakuan dengan uji $\mathrm{BNT}_{5 \%}$ :

a. Jika nilai selisih $\leq$ nilai $\mathrm{BNT}_{5 \%}$; antar perlakuan tidak berbeda nyata,

b. Jika nilai selisih $\geq \mathrm{BNT}_{5 \%}$; antar perlakuan berarti berbeda nyata.

Analisis selektivitas dilakukan terhadap hasil tangkapan tarjet yaitu rajungan (Portunus pelagicus). Data yang digunakan untuk keperluan analisis selektivitas adalah ukuran lebar karapas (carapace width) rajungan. Mengacu pada Tokai (1996), kurva selektivitas ukuran mata jaring didefinisikan sebagai peluang rajungan untuk tertahan, tidak lolos melewati bukaan mata jaring terpasang, pada saat sudah 
berada di dalam bubu lipat. Selektivitas mata jaring dinyatakan sebagai fungsi dari rasio antara ukuran lebar karapas rajungan terhadap bukaan mata jaring yang bentuk persamaannya adalah sebagai berikut:

$$
S(l)=\frac{1}{[(1+\exp (\alpha+\beta * l)]}
$$

$\alpha$ dan $\beta$ : parameter-parameter dari model logistik dihitung melalui pendekatan maximum likelihood method (Tokai, 1997).

$S($ ) : : fungsi dari selektivitas terhadap lebar karapas rajungan.

\section{HASIL DAN BAHASAN}

Hasil

\section{Komposisi Jenis Tangkapan}

Total hasil tangkapan rajungan dari bubu lipat selama uji coba penangkapan tercatat sebanyak $491,01 \mathrm{~kg}$. Komposisi antara target spesies (tangkapan rajungan) dengan hasil tangkap sampingan (non rajungan/jenis biota lainnya) untuk masing-masing tipe bubu lipat $A, B, C$ dan $D$ masing masing $60,36 \mathrm{~kg}$ dan $164,71 \mathrm{~kg} ; 63,07 \mathrm{~kg}$ dan 52,23 $\mathrm{kg} ; 47,49 \mathrm{~kg}$ dan $38,15 \mathrm{~kg} ; 38,32 \mathrm{~kg}$ dan $26,24 \mathrm{~kg}$. Komposisi jenis rajungan didominasi oleh jenis Portunus pelagicus sedang jenis lain seperti rajungan karang (Charybdis fariatus) dan rajungan angin (Podophthalmus vigi) tertangkap hanya beberapa ekor saja.

Untuk kategori hasil tangkap sampingan (bycatch) beberapa jenis ikan yang banyak tertangkap dan memiliki nilai ekonomi penting antara lain tiga waja, gulamah (Scianidae), kuniran (Uepenus spp.), sotong (Sepia spp.), gurita (Octopodidae).

\section{Rataan Hasil Tangkapan Rajungan}

Rataan hasil tangkapan rajungan (Portunus pelagicus) per setting untuk masing masing tipe bubu A, B, C dan D berturut-turut sebanyak $2,08 \mathrm{~kg} ; 2,17 \mathrm{~kg}$; $1,64 \mathrm{~kg}$ dan $1,32 \mathrm{~kg}$. Secara rinci perolehan hasil tangkapan rajungan dan hasil tangkap sampingan (HTS) selama ujicoba penangkapan disajikan pada Tabel 1.

Berdasarkan hasil analisa sidik ragam (ANOVA) diperoleh nilai $F_{\text {Hitung }}>F_{\text {Tabel }}(5,394>1,610)$, menunjukan bahwa ukuran mata jaring yang digunakan pada bubu lipat berpengaruh nyata terhadap hasil tangkapan rajungan (pada taraf uji $5 \%$ ). Pada uji lanjutan (uji-BNT) terhadap masing-masing tipe bubu yang digunakan menunjukkan tidak diperoleh perbedaan nyata hasil tangkapan rajungan antara bubu ukuran mata jaring 11/4 inci dengan 2 inci, demikian pula antara ukuran mata jaring $21 / 2$ inci dan 3 inci. Perbedaan yang nyata ditemukan pada bubu

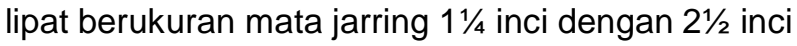
dan 3 inci, serta 2 inci dengan 21/2 inci dan 3 inci.

\section{Struktur Ukuran Hasil Tangkapan Rajungan}

Hasil pengukuran terhadap rajungan sebagai hasil tangkapan tarjet tercatat kisaran lebar karapas berkisar antara 5,5-23,5 cm. Ukuran rajungan terkecil dan terbesar tertangkap oleh bubu lipat yang menggunakan ukuran mata jaring 11/4 inci. Sebaran ukuran lebar karapas rajungan yang tertangkap bubu lipat untuk masing masing tipe bubu dengan ukuran mata jaring yang digunakan disajikan dalam Gambar 4. 
Tabel 1. Hasil tangkapan rajungan dan hasil tangkap sampingan $(\mathrm{kg})$ bubu lipat selama uji coba di perairan utara Lamongan Jawa Timur

Table 1. Blue swimming crab catch and bycatch $(\mathrm{kg})$ caught by collapsible pot during fishing trials in north of Lamongan, East Java

\begin{tabular}{|c|c|c|c|c|c|c|c|c|}
\hline \multirow{3}{*}{$\begin{array}{c}\text { No. } \\
\text { Setting }\end{array}$} & \multirow{2}{*}{\multicolumn{2}{|c|}{$\begin{array}{c}\text { Bubu A } \\
\text { mesh size 11/4 inch }\end{array}$}} & \multirow{2}{*}{\multicolumn{2}{|c|}{$\begin{array}{c}\text { Bubu B } \\
\text { mesh size } 2 \text { inch }\end{array}$}} & \multirow{2}{*}{\multicolumn{2}{|c|}{$\begin{array}{c}\text { Bubu C } \\
\text { mesh size } 2^{1 / 2} \text { inch } \\
\end{array}$}} & \multirow{2}{*}{\multicolumn{2}{|c|}{$\begin{array}{c}\text { Bubu D } \\
\text { mesh size } 3 \text { inch }\end{array}$}} \\
\hline & & & & & & & & \\
\hline & P. pelagicus & Bycatch & P.pelagicus & Bycatch & P.pelagicus & Bycatch & P. pelagicus & Bycatch \\
\hline 1 & 2,01 & 8,47 & 4,17 & 1,19 & 2,78 & 0,3 & 0,97 & - \\
\hline 2 & 3,16 & 3,42 & 2,79 & 1,18 & 1,73 & 0,23 & 1,37 & - \\
\hline 3 & 2,96 & 10,96 & 3,02 & 0,95 & 2,14 & 0,53 & 2,28 & 0,41 \\
\hline 4 & 1,64 & 4,68 & 1,93 & 0,81 & 1,19 & 0,63 & 1,07 & 0,4 \\
\hline 5 & 2,98 & 2,67 & 3,22 & 0,24 & 1,48 & 0,03 & 2,05 & 0,11 \\
\hline 6 & 1,64 & 5,36 & 2,85 & 0,74 & 2,35 & 0,37 & 2,07 & 0,23 \\
\hline 7 & 2,24 & 9,08 & 3,09 & 1,4 & 1,87 & 0,55 & 0,58 & 0,24 \\
\hline 8 & 1,96 & 7,46 & 2,38 & 1,44 & 0,86 & 0,65 & 0,83 & 0,86 \\
\hline 9 & 1,02 & 5,7 & 0,62 & 1,09 & 1,85 & 0,31 & 1,19 & 0,41 \\
\hline 10 & 2,08 & 7,68 & 1,69 & 1,25 & 1,05 & 1,29 & 1,47 & 0,47 \\
\hline 11 & 1,32 & 4,03 & 1,3 & 3,06 & 0,97 & 1,45 & 0,37 & 1,77 \\
\hline 12 & 0,93 & 10,8 & 1,05 & 2,88 & 0,92 & 2,41 & 1,19 & 1,84 \\
\hline 13 & 1,75 & 1,15 & 1,1 & 1,41 & 0,53 & 1,32 & 1,19 & 0,43 \\
\hline 14 & 1,73 & 4,52 & 0,49 & 1,2 & 0,51 & 0,93 & 0,96 & 0,97 \\
\hline 15 & 3,81 & 4,7 & 1,57 & 1,57 & 1,9 & 3,12 & 1,28 & 1,09 \\
\hline 16 & 2,68 & 7,39 & 1,24 & 4,32 & 2,43 & 2,47 & 1,6 & 2,55 \\
\hline 17 & 2,06 & 7,45 & 2,04 & 3,29 & 2,02 & 2,14 & 0,73 & 2,79 \\
\hline 18 & 1,22 & 4,91 & 1,32 & 1,08 & 1,42 & 0,9 & 1,34 & 0,28 \\
\hline 19 & 3,35 & 2,75 & 3,53 & 1,41 & 2,62 & 0,23 & 1,91 & 0,29 \\
\hline 20 & 3,88 & 2,33 & 5,38 & 1,11 & 2,01 & 0,29 & 1,75 & 0,09 \\
\hline 21 & 1,02 & 4,42 & 1,12 & 2,06 & 0,72 & 2.00 & 0,28 & 1,01 \\
\hline 22 & 1,02 & 5,67 & 0,8 & 3,14 & 0,78 & 2,83 & 1,05 & 0,96 \\
\hline 23 & 0,8 & 4,84 & 1,49 & 2,29 & 1,54 & 2,25 & 0,56 & 1,21 \\
\hline 24 & 1,26 & 2,9 & 1,39 & 1,68 & 1,16 & 1,2 & 0,46 & 0,4 \\
\hline 25 & 2,92 & 6,42 & 3,94 & 2,06 & 2,21 & 2,57 & 1,96 & 1,81 \\
\hline 26 & 2,86 & 5,77 & 1,66 & 3,3 & 1,27 & 1,61 & 1,75 & 0,89 \\
\hline 27 & 2,92 & 5,34 & 3,36 & 1,9 & 2,81 & 2,03 & 2,83 & 2,04 \\
\hline 28 & 1,62 & 6,47 & 2,63 & 2,34 & 1,7 & 1,85 & 1,32 & 1,11 \\
\hline 29 & 1,51 & 7,37 & 1,91 & 2,84 & 2,64 & 1,63 & 1,91 & 1,58 \\
\hline Total & 60,36 & 164,71 & 63,07 & 53,23 & 47,49 & 38,15 & 38,32 & 26,24 \\
\hline Rataan & 2,08 & 5,68 & 2,17 & 1,84 & 1,64 & 1,32 & 1,32 & 0,9 \\
\hline
\end{tabular}


Tabel 2. Hasil analisis ANOVA terhadap hasil tangkapan rajungan dari bubu lipat

Table 2. Result of ANOVA analysis on the catch of blue swimming crab cought by collapsible pot

\begin{tabular}{|c|c|c|c|c|c|c|}
\hline \multicolumn{7}{|l|}{ ANOVA } \\
\hline Source of Variation & SS & $d f$ & MS & Fhitung & $P$-value & F crit \\
\hline Kelompok & 55,39273 & 28 & 1,978312 & 5,394088 & $9,45 \mathrm{E}-10$ & 1,610415 \\
\hline Perlakuan & 13,78886 & 3 & 4,596286 & 12,53229 & 7,53E-07 & 2,713227 \\
\hline Galat & 30,80747 & 84 & 0,366756 & & & \\
\hline Total & 99,98905 & 115 & & & & \\
\hline
\end{tabular}

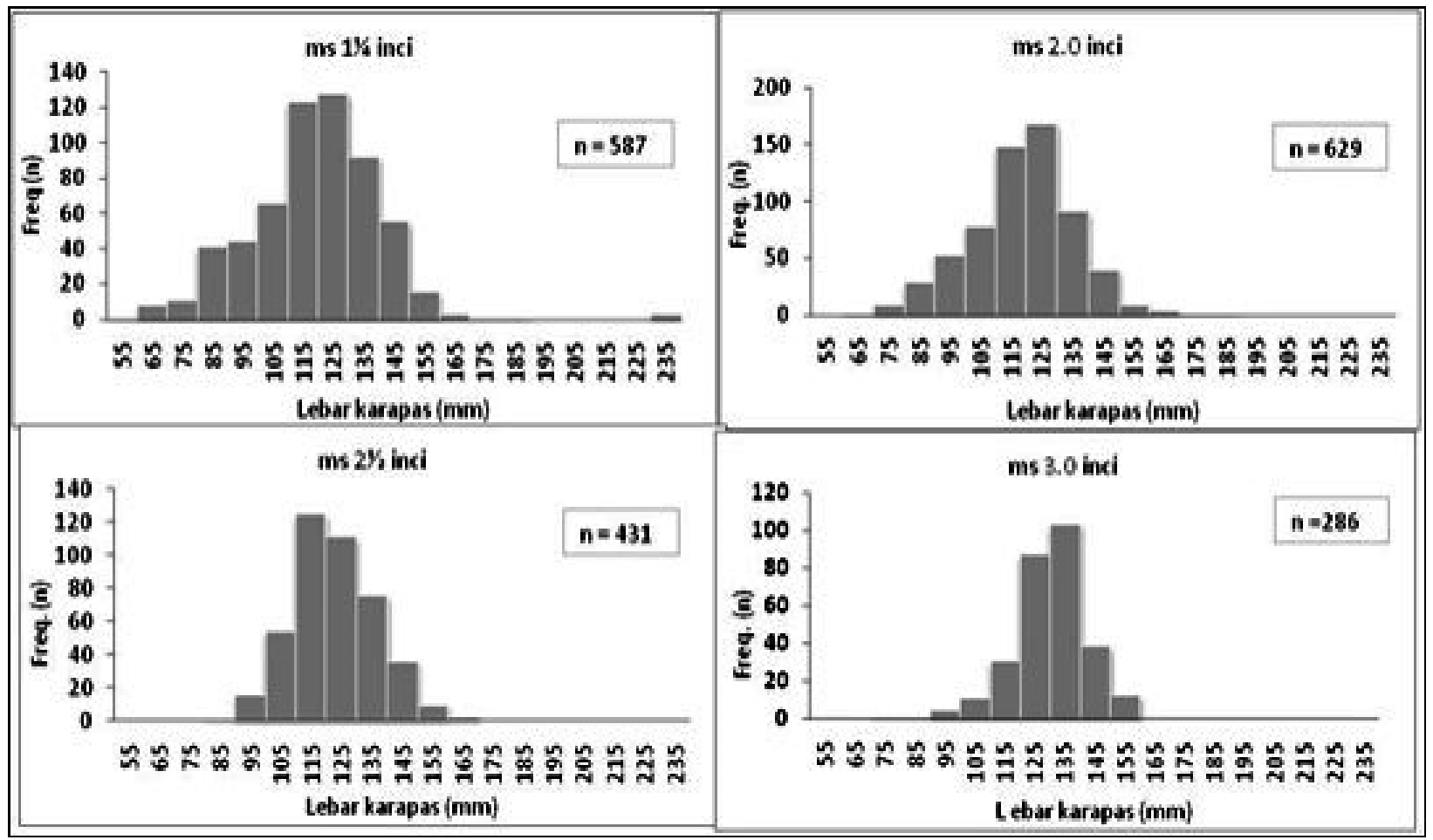

Gambar 4. Sebaran ukuran lebar karapas $(\mathrm{mm})$ rajungan (Portunus pelagicus) hasil tangkapan bubu lipat dengan ukuran mata jaring $(\mathrm{ms}) 1 \frac{1}{4}, 2,2 \frac{1}{2}$ dan 3 inci

Figure 4. Carapace width $(\mathrm{mm})$ distribution of blue swimming crab (Portunus pelagicus) caught by 11/4, 2, $21 / 2$, and 3 inch mesh sizes of collapsible pot.

Proporsi hasil tangkapan rajungan berdasarkan Peraturan Menteri Kelautan dan Perikanan (Permen Men.KP 01/Tahun 2015) terkait dengan ukuran rajungan $(\mathrm{CW}=10 \mathrm{~cm})$ yang diperbolehkan untuk ditangkap disajikan pada Gambar 5.
Kurva selektivitas (Gambar 6) menunjukan bahwa ukuran lebar karapas rajungan yang banyak tertangkap $\left(\mathrm{CW}_{50 \%}\right)$ untuk masing masing ukuran mata jaring $(11 / 4$, 2, 21/2 dan 3 inci) masing-masing adalah 122, 121, 123 dan $132 \mathrm{~mm}$. Seluruh nilai $\mathrm{C}_{\mathrm{w} 50 \%}$ berada di atas ukuran lebar karapas rajungan yang diperbolehkan ditangkap, sesuai dengan aturan yang berlaku. 


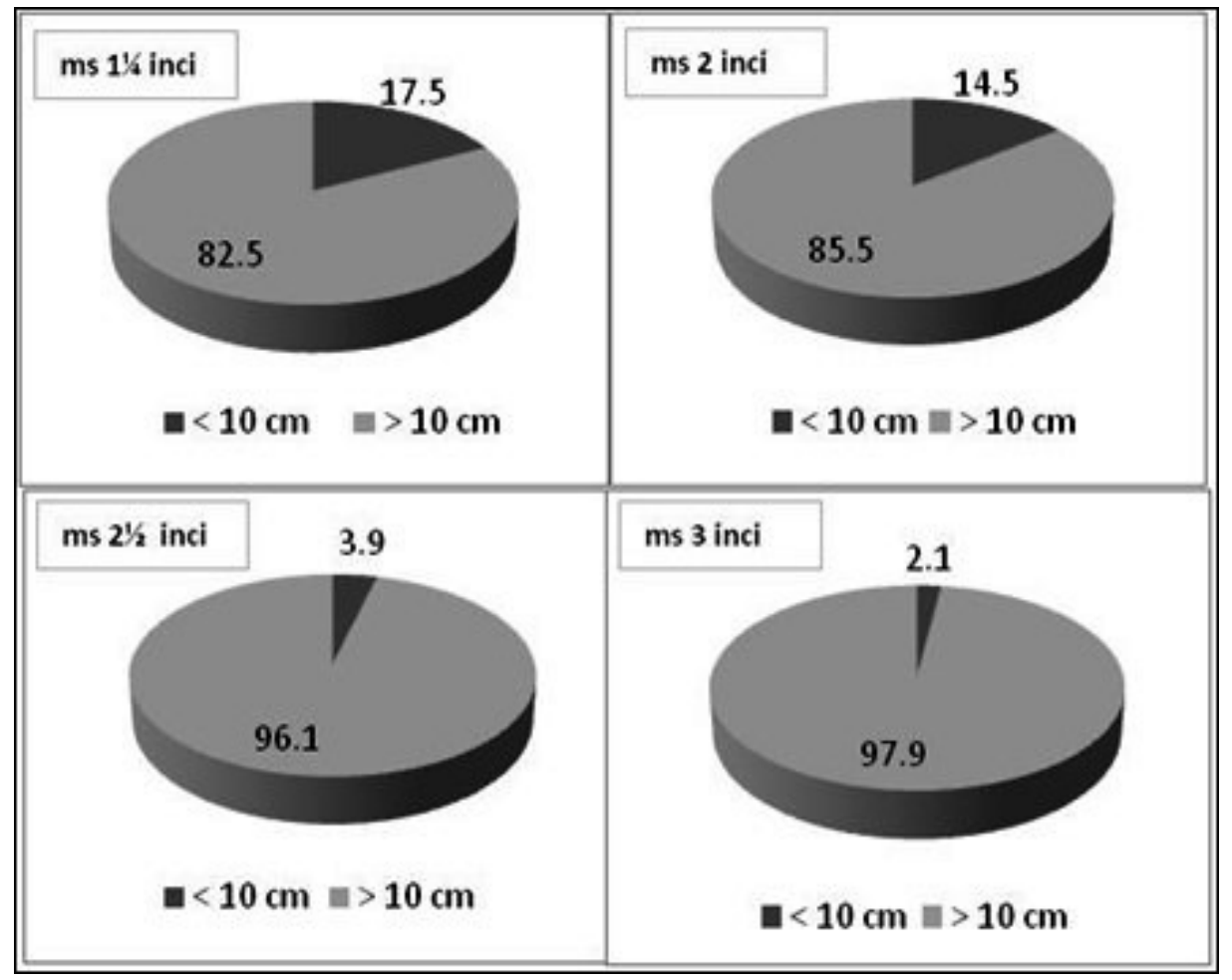

Gambar 5. Prosentase (\%) hasil tangkapan rajungan berdasarkan batas ukuran lebar karapas yang boleh ditangkap $\left(\mathrm{C}_{\mathrm{w}}>10 \mathrm{~mm}\right)$ pada bubu lipat dengan ukuran mata jaring $(\mathrm{ms})$ 11/4, 2, 21/2 dan 3 inci.

Figure 5. Percentage of blue swimming crab (Portunus pelagicus) catch sizes compared to allowable legal size $\left(C_{w}>100 \mathrm{~mm}\right)$ for $11 / 4,2,21 / 2$ dan 3 inch mesh size collapsible pot.

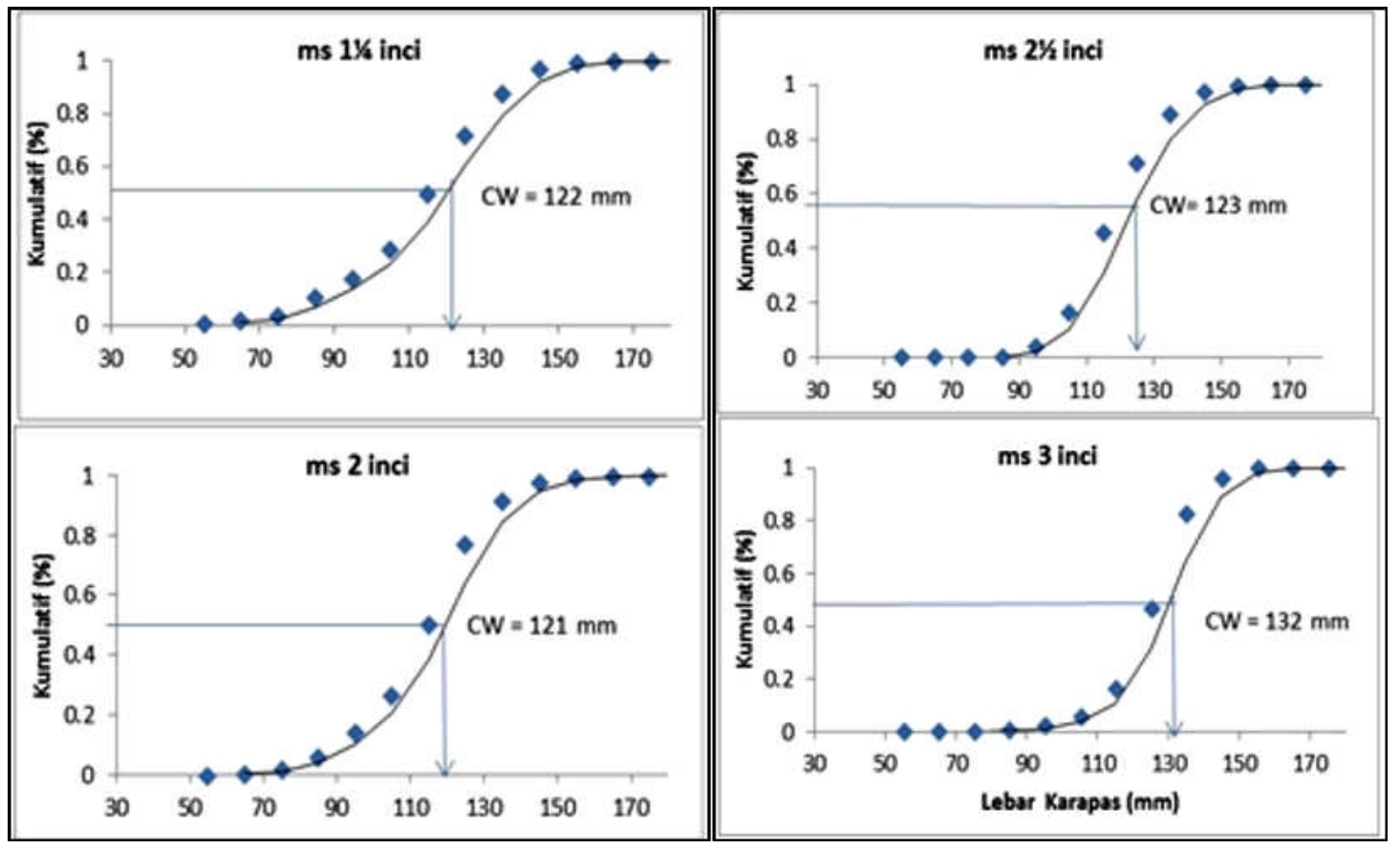

Gambar 6 . Kurva selektivitas rajungan yang tertangkap bubu lipat dengan ukuran mata jaring 11/4, 2, 21/2 dan 3 inci.

Figure 6. Blue swimming crab selection curve of collapsible pot with 11/4,2, 21/2 and 3 inch mesh size. 


\section{Bahasan}

Ukuran dan bentuk mata jaring yang dipasangkan merupakan salah satu faktor yang menentukan kinerja selektivitas bubu lipat rajungan terhadap hasil tangkapan. Uji coba pengoperasian bubu lipat rajungan memberikan informasi adanya perbedaan jumlah hasil tangkapan dan ukuran rajungan yang tertangkap pada setiap tipe bubu dengan ukuran mata jaring yang dipasang dalam bentuk mata jaring terbuka secara bujur sangkar (square mesh).

Bubu lipat rajungan yang menggunakan ukuran mata jaring 11/4 inci (bubu tipe A) menghasilkan total hasil tangkapan tertinggi $(225,06 \mathrm{~kg})$, dan terendah ditemukan pada tipe bubu $\mathrm{D}$ berukuran mata jaring 3 inci $(64,56 \mathrm{~kg})$ selama pelaksanaan uji coba penangkapan. Bertambahnya ukuran mata jaring yang digunakan cenderung menurunkan jumlah individu hasil tangkapan bubu lipat rajungan. Kondisi ini dapat dipahami karena, dengan ukuran mata jaring yang bertambah lebar, yang terpasang secara permanen (fixed) di seluruh bagian konstruksi bubu, meningkatkan kesempatan yang lebih besar kepada rajungan untuk meloloskan diri dari perangkap bubu. Penelitian bentuk celah pelolosan (bujur sangkar, segi empat, lingkaran dan elip) pada bubu lipat rajungan menunjukkan bahwa, prosentase tertinggi rajungan yang lolos $(70 \%)$ ditemukan pada celah pelolosan bentuk persegi empat yang memiliki ukuran luas terbesar (Boutson et al., 2009). Selanjutnya Guilorry \& Prejean (1997) dalam penelitiannya menyimpulkan bahwa, bentuk mata jarring hexagonal ukuran 3,81 $\mathrm{cm}$ dan square mesh ukuran $5,08 \mathrm{~cm}$ pada bubu merupakan mata jaring paling efektif mengurangi tangkapan rajungan (Callinectes spidus) yaitu berukuran di bawah standar (legal size). Dalam penelitian ini total hasil tangkapan bubu lipat tipe $A$ (mesh size 1,25 inci) lebih tinggi dibandingkan dengan bubu B, C maupun bubu D. Hasil tangkapan rajungan tertinggi ditemukan pada bubu B (mesh size 2 inci), dengan nilai rataan sebesar $2,17 \mathrm{~kg} /$ setting.Tangkapan rajungan terendah ditemukan pada bubu $D$ (mesh size 3 incl) sebesar $1,32 \mathrm{~kg} /$ setting. Hasil analisis menunjukkan bahwa ukuran mata jaring berpengaruh terhadap jumlah tangkapan rajungan. Analisis lanjut mengindikasikan bahwa jumlah tangkapan rajungan antara bubu $\mathrm{A}$ (mesh size 11/4 inci) dengan bubu $\mathrm{B}$ (mesh size 2 inci) tidak berbeda nyata. Namun untuk bubu C (mesh size 21/2 inci) dan $\mathrm{D}$ (mesh size 3 inci) yang memiliki ukuran mata jaring lebih besar, ditemukan perbedaan tangkapan yang cukup tinggi bila disandingkan dengan bubu $\mathrm{A}$ (mesh size 11/4 incl). Dikaitkan dengan ketersediaan ukuran sumberdaya rajungan dan pada saat dilakukan penelitian, hal ini mengindikasikan pengaruh perbedaan ukuran mata jaring yang relatif kecil $(3 / 4$ inci $=19.05 \mathrm{~mm}$ ) terhadap bubu A (mesh size 11/4 incl) menjadikan tangkapan rajungan bubu $\mathrm{B}$ (mesh size 2 inci). yang relatif sama.

Hasil tangkapan sampingan (HTS) bubu lipat rajungan mengindikasikan adanya penurunan secara kwantitatif seiring dengan semakin meningkatnya ukuran mata jaring yang digunakan. Bukaan mata jaring yang lebih lebar memberikan kesempatan yang besar bagi HTS seperti jenis rajungan (karang, angin), ikan (tiga waja, gulamah, kuniran), sotong gurita dan kekerangan untuk meloloskan diri dari bubu. Pada perikanan bubu lipat rajungan diduga proses seleksi hasil tangkapan sekurangnya terjadi pada dua kejadian utama. Pertama, pada saat bubu dioperasikan (dipasang) di dasar perairan dimana ikan, rajungan dan biota lain memiliki kesempatan untuk keluar-masuk perangkap melalui mata jaring yang terbuka secara permanen. Kedua, pada saat pengangkatan bubu (posisi tergantung pada kolom air), hasil tangkapan yang terperangkap dalam bubu akan mengalami proses 'pengayakan'. Bukaan mata jaring yang permanen, menjadikan kesempatan lolos menjadi terbuka, khususnya untuk hasil tangkapan yang memiliki ukuran panjang atau lebar d" panjang diagonal mata jaring terpasang.

Mengubah konstruksi bubu lipat dengan cara memperbesar ukuran mata jaring sampai dengan ukuran tertentu ( 2 inci) terbukti dapat mengurangi HTS mencapai $>50 \%$, tanpa mengurangi target penangkapan (rajungan) secara signifikan. Kemampuan alat tangkap dalam memilah dan meminimalkan HTS merupakan hal penting bagi keberlanjutan sumberdaya dan lingkungan. Pascoe (1997) menyampaikan bahwa HTS adalah bagian hasil tangkapan yang bukan menjadi target operasi penangkapan, termasuk di dalamnya jenis target penangkapan dibawah ukuran yang diperbolehkan untuk ditangkap (legal size). HTS bubu lipat rajungan tidak terbatas hanya jenis tangkapan non rajungan. Hasil tangkapan rajungan berukuran muda/juvenile kurang dari ukuran matang gonad pertama $\left(\mathrm{C}_{\mathrm{wm}}\right)$ juga tergolong HTS. Rajungan merupakan spesies yang melakukan migrasi lokal (sedentary species), oleh karenanya nilai $\mathrm{C}_{w \mathrm{~m}}$ rajungan bervariasi, tergantung wilayah perairan (Kurnia et al., 2014). Beberapa hasil penelitian menyimpulkan bahwa nilai $\mathrm{C}_{\mathrm{wm}}$ rajungan di perairan utara Jawa adalah 10,7 cm (Ernawati et al., 2014), perairan selatan Kalimantan $12,4 \mathrm{~cm}$ (Sumiono et al., 2015) dan Belitung 11,8 cm (Ernawati et.al., 2014). Alat penangkapan rajungan yang memiliki kemampuan dalam memilah target penangkapan diperlukan sebagai upaya untuk menjamin keberlanjutan sumberdaya perikanan lainnya. 
Selektivitas pada jenis alat penangkapan ikan adalah kemampuan suatu alat tangkap untuk menangkap ukuran dan jenis ikan tertentu (Ferno \& Olsen, 1994). Kinerja selektif mata jaring bubu lipat yang digunakan dapat ditunjukkan oleh ukuran rajungan yang tertangkap. Ukuran lebar karapas $\left(C_{w}\right)$ rajungan yang tertangkap selama uji coba penangkapan berkisar antara $60 \mathrm{~mm}-170 \mathrm{~mm}$ (Gambar 4). Jumlah rajungan yang banyak tertangkap ditemukan pada ukuran $125 \mathrm{~mm}$ untuk tipe bubu $A$ (mesh size 11/4 incl), B (mesh size 2 incl) dan C (mesh size $2 \frac{1}{2}$ inci). Pada tipe bubu $\mathrm{D}$ (mesh size 3 incl) jumlah rajungan terbanyak dengan ukuran $135 \mathrm{~mm}$. Terjadi pergeseran ukuran terkecil lebar karapas rajungan yang tertangkap seiring dengan meningkatnya ukuran mata jaring. Pada tipe bubu $\mathrm{A}$ (mesh size 11/4 incl). ukuran terkecil ditemukan pada nilai $65 \mathrm{~mm}$, bubu B (mesh size 2 incl) pada ukuran $75 \mathrm{~mm}$ dan untuk bubu $\mathrm{C}$ (mesh size $2 \frac{1}{2}$ incl) dan $\mathrm{D}$ (mesh size 3 inci) lebih besar, yakni $95 \mathrm{~mm}$. Penggunaan ukuran mata jaring 3 inci dapat menurunkan bycatch rajungan muda/juvenile hingga mendekati ukuran rajungan yang boleh ditangkap > 100 mm (Permen KP 01/Tahun 2015). Analisis selektivitas terhadap data ukuran rajungan yang tertangkap menunjukkan bahwa rata- rata lebar karapas rajungan tertangkap $\left(\mathrm{C}_{\mathrm{W} 50 \%}\right)$ pada tipe bubu A (mesh size 11/4 incl), B (mesh size 2 incl), C (mesh size $2 \frac{1}{2}$ incl) dan $\mathrm{D}$ (mesh size 3 incl) masing masing berturut-turut sebesar 122, 121123 dan $132 \mathrm{~mm}$ (Gambar 8). Keempat ukuran mata jaring bubu lipat yang digunakan ternyata menghasilkan tangkapan rajungan dengan ukuran yang layak tangkap dalam porsi yang relative besar. Namun tidak terhindarkan tertangkapnya hasil tangkap sampingan, termasuk didalamnya rajungan muda, yang secara aturan belum layak tangkap, dengan tingkat persentase yang berbeda.

Proporsi tertangkapnya rajungan di bawah ukuran yang ditetapkan (legal size) terendah ditemukan pada bubu lipat dengan ukuran mata jaring 3 inci $(2,1 \%)$ dan tertinggi pada ukuran $1 \frac{11 / 4}{4}$ inci $(17.5 \%)$. Untuk ukuran mata jaring 2 dan $2 \frac{1}{2}$ inci masing masing 14.5 $\%$ dan $3.9 \%$ (Gambar 5). Penelitian selektivitas bubu lipat rajungan di perairan Sulawesi Tenggara melalui pemasangan celah pelolosan (escape vent) memberikan kesimpulan bahwa ukuran celah pelolosan $5 \times 3,5 \mathrm{~cm}$ paling sesuai oleh karena diperoleh hasil tangkapan rajungan dengan nilai $\mathrm{L}_{50 \%}$ $=10.74 \mathrm{~cm}$ (La Sara et al., 2016). Kurniasih et al. (2016) dalam penelitian di perairan Banten menyimpulkan bahwa posisi pemasangan celah pelolosan persegi panjang $(4 \times 3 \mathrm{~cm})$ pada bubu lipat yang efektif untuk penangkapan rajungan adalah pada bagian atas panel dengan persentase tangkapan rajungan layak tangkap sebesar $95 \%$. Sedangkan menurut Boutson et al. (2009) dalam penelitian di perairan Thailand mengemukakan bahwa celah pelolosan persegi panjang $(45 \times 35 \mathrm{~mm})$ yang dipasang di bagian bawah sisi panel menunjukan kinerja terbaik dalam meloloskan rajungan muda. Penggunaan celah pelolosan pada bubu lipat rajungan, terinsiprasi oleh beberapa hasil penelitian alat tangkap bubu untuk penangkapan kepiting bakau (Scylla spp), seperti dilakukan oleh Jirapunpipat et al. (2008), Iskandar (2012), Susanto \& Ririn (2013), Tallo, et al. (2014).

Terdapat perbedaan kinerja seleksi antara penggunaan celah pelolosan (escape vent) dengan ukuran mata jaring bentuk bujur sangkar (square mesh) untuk bubu lipat rajungan. Pada penggunaan celah pelolosan, kesempatan HTS untuk lolos dari perangkap bubu tergantung pada jumlah/luasan celah pelolosan yang dipasang pada dinding bubu. Sementara penerapan ukuran mata jaring, akan memberikan peluang bagi HTS keluar dari perangkap bubu melalui seluruh bagian dinding bubu yang terbungkus dengan jaring.

Permintaan pasar akan komoditas rajungan yang cenderung meningkat, harus dibarengi dengan persyaratan terkait dengan jaminan atas keberlanjutan sumberdaya (sustainability). Oleh sebab itu diperlukan praktek penangkapan yang bersifat selektif terhadap ukuran komoditas rajungan, sesuai dengan aturan yang berlaku. Bubu lipat merupakan alat tangkap yang efektif untuk menangkap rajungan, dan telah berkembang di masyarakat nelayan di pantai utara Jawa. Kinerja bubu lipat untuk menangkap rajungan, tidak terhindarkan tertangkapnya HTS, termasuk di dalamnya rajungan ukuran kecil/muda. Pengaturan ukuran mata jaring untuk bubu lipat secara praktis lebih mudah dilakukan, dalam upaya menurunkan hasil tangkapan rajungan ukuran kecil/ juvenil dan HTS jenis biota lainnya.

\section{KESIMPULAN}

Ukuran mata jaring bubu berpengaruh terhadap jumlah tangkapan rajungan. Hasil tangkapan rajungan tipe bubu A (mesh size 11/4 incl) dan bubu B (mesh size 2 incl) berbeda nyata dengan bubu $\mathrm{C}$ (mesh size $2 \frac{1}{2}$ inci) dan bubu D (mesh size 3 inci). Tangkapan rajungan antara tipe bubu $A(2,08 \mathrm{~kg} / \mathrm{setting})$ dengan B $(2,17 \mathrm{~kg} /$ setting $)$, serta bubu C $(1,64 \mathrm{~kg} /$ setting $)$ dengan bubu $D(1,32 \mathrm{~kg} / \mathrm{setting})$ tidak terdapat perbedaan yang nyata/signifikan. Prosentase ukuran lebar karapas rajungan layak tangkap ( $>100 \mathrm{~mm}$ ) semakin meningkat nilainya dengan bertambah besarnya ukuran mata jaring. Nilai tertinggi ditemukan 
pada bubu lipat dengan ukuran mata jaring 3 inci sebesar $97,9 \%$, dan terendah mata jaring $1 \frac{11 / 4}{\text { inci }}$ yaitu $82,5 \%$. Penggunaan ukuran mata jaring 2 inci pada alat tangkap bubu lipat tercatat efektif mengurangi HTS (>60\%), dengan tanpa menurunkan hasil tangkapan rajungan.

\section{PERSANTUNAN}

Tulisan ini merupakan bagian dari hasil penelitian dengan judul Desain Dan Konstruksi Alat Tangkap Rajungan (Portunus Pelagicus) yang Selektif dan Ramah Lingkungan Tahun Anggaran 2015, di Balai Penelitian Perikanan Laut Muara Baru, Jakarta.

\section{DAFTAR PUSTAKA}

Boutson, A., Mahasawasde, C., Mahasawasde, S., Tunkijjanukij, S. \& Arimoto, T. (2009). Use of escape vents to improve size and species selectivity of collapsible pot for blue swimming crab Portunus pelagicus in Thailand. Fish Sci. 75, 2533. DOI: 10.1007/s12562-008-0010-z.

DJPT. (2016). Statistik perikanan Tangkap Indonesia Tahun 2015. Direktorat Jenderal Perikanan Tangkap, KKP. Jakarta.

Ernawati, T., Kembaren, D. \& Wagiyo, K. (2015). Penentuan status stok sumberdaya rajungan (Portunus Pelagicus Linnaeus, 1758) dengan metode spawning potential ratio di perairan sekitar Belitung. J. Lit. Perikan. Ind, 21 (2), 63-70. DOI: http://dx.doi.org/10.15578/jppi.21.2.2015.6370

Ferno, A., \& Olsen, S. (1994). Marine fish behaviour in capture abundance estimation (p. 69-81). London: Fishing News Book.
Guilorry, V., \& Prejean. P. (1997). Blue crab, Callinectes sapidus, Trap Selectivity Studies: Mesh Size. Mar. Fish. Rev, 59 (1), 29-31.

Hufiadi. (2017). Selektivitas alat tangkap rajungan (Portunus pelagicus) di Laut Jawa (Studi kasus alat tangkap Cirebon). (p. 131-138). Prosiding Simposium Nasional Krustasea.

Jirapunpipat, K., Phomikong, P., Yokota, M., \& Watanabe, S. (2008). The effect of escape vents in collapsible pots on catch and size of the mud crab Scylla olivacea. Fish Res, 94, 73-78.

Kurnia, R., M. Boer \& Zairion. (2014). Biologi populasi rajungan (Portunus pelagicus) dan karakteristik lingkungan habitat esensinya sebagai upaya awal perlindungan di Lampung Timur. JIPI, 19(1), 2228.

Kurniasih, A., Irnawati, R., \& Susanto, A. (2016). Efektifitas celah pelolosan pada bubu lipat terhadap hasil tangkapan rajungan di Teluk Banten. Jurnal Perikanan dan Kelautan, 6 (2), 95 - 103.

La Sara, Halili, Mustafa, A., \& Bahtiar. (2016). Appropriate escape vent sizes on collapsible crab pot for blue swimming crab (Portunus pelagicus) Fishery in Southeast Sulawesi Waters, Indonesia. J. Fish. Aquat. Sci. 11:402-410. DOI: 10.3923/ jfas.2016.

Pascoe, S. (1997). Bycatch management and the economic of discarding, FAO Fisheries Technical Paper No. 370. Rome, Italy: FAO. 